\title{
Metals in Calluna vulgaris, Empetrum nigrum, Festuca vivipara and Thymus praecox ssp. arcticus in the geothermal areas of Iceland
}

\author{
Adam Rajsz $^{1}$ • Bronisław Wojtuń ${ }^{1}$ - Aleksandra Samecka-Cymerman ${ }^{1}$ (I) $\cdot$ Paweł Wąsowicz $^{2} \cdot$ Lucyna Mróz $^{1}$. \\ Andrzej Rudecki ${ }^{1}$. Alexander J. Kempers ${ }^{3}$
}

Received: 29 January 2021 / Accepted: 17 June 2021 / Published online: 10 July 2021

(C) The Author(s) 2021

\begin{abstract}
This investigation was conducted to identify the content of metals in Calluna vulgaris (family Ericaceae), Empetrum nigrum (family Ericaceae), Festuca vivipara (family Poaceae) and Thymus praecox subsp. arcticus (family Lamiaceae), as well as in the soils where they were growing in eight geothermal heathlands in Iceland. Investigation into the vegetation of geothermal areas is crucial and may contribute to their proper protection in the future and bring more understanding under what conditions the plants respond to an ecologically more extreme situation. Plants from geothermally active sites were enriched with metals as compared to the same species from non-geothermal control sites (at an average from about $150 \mathrm{~m}$ from geothermal activity). The enriched metals consisted of $\mathrm{Cd}, \mathrm{Co}, \mathrm{Cu}, \mathrm{Fe}$ and $\mathrm{Ni}$ in C. vulgaris; $\mathrm{Cd}, \mathrm{Mn}$ and $\mathrm{Ti}$ in E. nigrum; $\mathrm{Hg}$ and $\mathrm{Pb}$ in $\mathrm{F}$. vivipara; and $\mathrm{Cd}, \mathrm{Fe}$ and Hg in T. praecox. Notably, C. vulgaris, E. nigrum, F. vivipara and T. praecox had remarkably high concentrations of Ti at levels typical of toxicity thresholds. $\mathrm{Cd}$ and $\mathrm{Pb}$ (except for $C$. vulgaris and $F$. vivipara) were not accumulated in the shoots of geothermal plants. C. vulgaris from geothermal and control sites was characterised by the highest bioaccumulation factor (BF) of Ti and $\mathrm{Mn} ;$ E. nigrum and $F$. vivipara by the highest $\mathrm{BF}$ of $\mathrm{Ti}$ and $\mathrm{Cr}$; and $T$. praecox by the highest $\mathrm{BF}$ of Ti and $\mathrm{Zn}$ compared to the other elements. In comparison with the other examined species, $F$. vivipara from geothermal sites had the highest concentration of Ti in above-ground parts at any concentration of plant-available Ti in soil.
\end{abstract}

Keywords Trace element $\cdot$ Bioindication $\cdot$ Low Arctic

\section{Introduction}

Iceland, an island situated in the Atlantic Ocean, has areas of volcanic activity from southwest to northeast, and geothermal areas occur (Elmarsdóttir et al. 2015). Such zones are of various sizes, elevation, climatic conditions and geothermal

\section{Responsible Editor: Elena Maestri}

Aleksandra Samecka-Cymerman

aleksandra.samecka-cymerman@uwr.edu.pl

Adam Rajsz

adam.rajsz@uwr.edu.pl

Bronisław Wojtuń

bronislaw.wojtun@uwr.edu.pl

Paweł Wasowicz

pawel@ni.is

Lucyna Mróz

lucyna.mroz@uwr.edu.pl activity. Thus, geothermal activity is common in Iceland, but the associated unique environment (frequently remaining pristine) at the surface is usually small and occurs in patches. Such zones produce a very special stress-inducing environment and microclimatic conditions for plant development being less dependent on the climate (Burns and Leathwick 1995). They are

Andrzej Rudecki
andrzej.rudecki@uwr.edu.pl

Alexander J. Kempers

lexkempers@science.ru.nl

1 Department of Ecology, Biogeochemistry and Environmental Protection, Wrocław University, ul. Kanonia 6/8, 50-328 Wrocław, Poland

2 Icelandic Institute of Natural History, Akureyri, Iceland

3 Department of Environmental Science, Institute for Water and Wetland Research, Radboud University, Huygens Building, Heijendaalseweg 135, 6525 Nijmegen, AJ, Netherlands 
characterised by high soil temperatures, higher humidity from steam evaporating vents and a specific $\mathrm{pH}$ range from acidic to alkaline accompanied by elevated levels of metals and metalloids, especially As and Ti (Glime 2007; Chiarucci et al. 2008; Wilberscheid 2008; Boothroyda 2009). According to Stout and Al-Niemi (2002) and Nishar et al. (2017), high soil temperatures seem to be the most important factor that determines the types of plant species in such areas. The stably elevated temperatures are additionally advantageous for plants of the geothermal zones in a cold climate (Wilberscheid 2008). Regular availability of moisture in such habitats with low natural water retention and low amounts of organic matter may produce special conditions for plants to survive. Additionally light intensity in the Nordic latitudes is probably an important factor owing to which vegetation can withstand the heat. The symbiotic fungi which provide nutrient supply produce melanin for complexing oxygen radicals. This activate systems responding to stress more quickly than in plants with no mycorrhiza and also provide protection for plants to cope with the high temperatures of geothermal zones (Redman et al. 2002). The vegetation systems of the Icelandic geothermal zones are yet to be fully investigated. The parameters of interest are usually soil temperature, $\mathrm{pH}$ and organic carbon concentration (Wilberscheid 2008; Elmarsdóttir et al. 2015). These reports do not discuss the influence of biogeochemical features on species distribution. Data about the level of rare minerals in plants and soils in Iceland could not be found in the literature. Therefore, this investigation was conducted to identify the content of potentially contaminating elements $\mathrm{As}, \mathrm{Cd}, \mathrm{Co}, \mathrm{Cr}, \mathrm{Cu}, \mathrm{Fe}, \mathrm{Hg}, \mathrm{Mn}$, $\mathrm{Ni}, \mathrm{Pb}, \mathrm{Ti}$ and $\mathrm{Zn}$ in Calluna vulgaris (L.) Hull, Empetrum nigrum L., Festuca vivipara (L.) Sm. and Thymus praecox subsp. arcticus (Durland) Jalas, abridged in this article as T. praecox (Wassowicz 2020). The same minerals were determined in the soils where the plants were growing in eight geothermal heathlands in Iceland (Ottósson et al. 2016) as well as in the control sites surrounding the heathlands and not influenced by geothermal activity. C. vulgaris is a pioneering and one of the most widespread species able to survive in the harsh environmental conditions of waste heaps or geothermal fields with a range of $\mathrm{pH}$ of 2.0-7.0 and in nutrient-poor soils with temperatures as high as $55{ }^{\circ} \mathrm{C}$ (Engelskjøn et al. 2003; Chiarucci et al. 2008; Marrs and Bannister 2006; Lottermoser et al. 2011; Bartoli et al. 2013; Pippucci et al. 2015). E. nigrum is a species with a broad ecological amplitude that tolerates various types of substrates with $\mathrm{pH}$ of 2.5-7.7 (Monni et al. 2000; Monschein et al. 2010). It has been found in acidic habitats of Norway and has been reported to be able to detoxify or avoid uptake of, for example, excessive Al (Gjengedal et al. 2015). The species, tolerant to metals and surviving in very polluted sites, e.g. in the vicinity of smelters, is able to concentrate high levels of $\mathrm{Cu}$ and $\mathrm{Ni}$ (Monni et al. 2000; Monni et al. 2001;
Zverev et al. 2008). F. vivipara belongs to a genus with a potential for evolving genetic adaptations in response to environmental conditions and especially elevated levels of metals and metalloids (Dradrach et al. 2020). This species has been found in Icelandic geothermal areas with soil temperatures of 15-98 ${ }^{\circ} \mathrm{C}$ (Elmarsdóttir et al. 2015). T. praecox grows in various sites such as gravelly soils, lava fields and meadows also including geothermal zones from North to Central Europe, Eastern North America, Greenland and Iceland (Pigott 1955; Kristinsson 2010). The tested hypothesis was that plants from geothermal zones contain significantly higher concentrations of metals than identical species from surrounding control sites away from high soil temperatures. Future protection of vegetation in geothermal areas is important, and this investigation enables better understanding on how plants in these areas respond to more extreme environmental factors.

\section{Materials and methods}

\section{Sampling design}

Samples were collected in heathland sites 1-8 (Fig. 1) influenced by geothermal activity and in nearby control sites without geothermal activity (at an average distance of about $150 \mathrm{~m}$ from geothermal activity) (Bartoli et al. 2013). It was not possible to separately mark the locations of geothermal and corresponding control sites with the scale of Fig. 1. Thus, sampling site numbers refer to both geothermal and their corresponding control sites. In each geothermal and control site, 3 squares of $25 \mathrm{~m} \times 25 \mathrm{~m}$ were selected randomly, and in each square, above-ground biomass of $C$. vulgaris (except for geothermal sites 4 and 5 and control sites 2-5), E. nigrum (except for geothermal site 3), F. vivipara (except for control sites 6-8) and T. praecox (except for control sites 6 and 7) together with the topsoil (0-15-cm depth) was collected in 3 replicates. Plant samples were not washed (Aboal et al. 2011; Oliva and Valdés 2004). Samples were collected within the continental subarctic climate $(D f c)$ (Peel et al. 2007). Soil types were Brown Andosol (sites 1, 3-5), Leptosol (site 2) and Cambic VitrisolSandy Vitrisol (sites 6-8) (Arnalds and Óskarsson 2009).

\section{Soil and plant analysis}

Soil temperature was measured at a depth of $10 \mathrm{~cm}$ with a Pt-101 electronic thermometer (Elmetron). Soil samples previously cleaned from organic matter were passed through a 2-mm sieve (Morek Multiserw LPzE-2e). The total content of trace elements was analysed in soils homogenised in a Fritsch Pulverisette 2 mortar grinder, and the content of plant-available trace elements was determined in soils homogenised in a mortar with pestle. Plantavailable concentrations $\left(\mathrm{mg} \mathrm{kg}^{-1}\right)$ of $\mathrm{As}, \mathrm{Cd}, \mathrm{Co}, \mathrm{Cr}, \mathrm{Cu}$, 


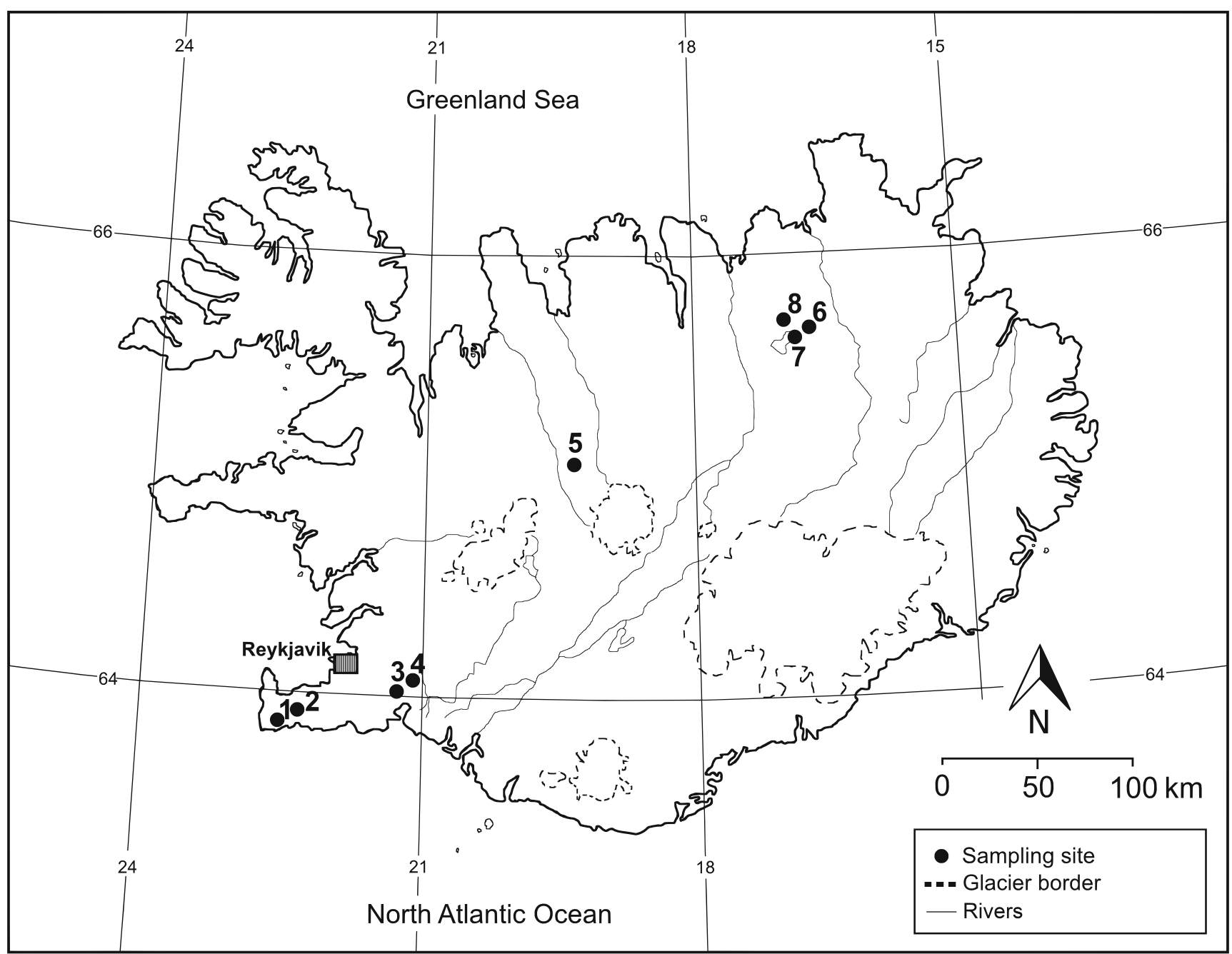

Fig. 1 Location of the sampling sites

$\mathrm{Fe}, \mathrm{Mn}, \mathrm{Ni}, \mathrm{Pb}$, Ti and $\mathrm{Zn}$ in soil were analysed by extraction with $1 \mathrm{M}$ ammonium acetate-EDTA $(\mathrm{pH} 4.65)$ for $30 \mathrm{~min}$ ( $5 \mathrm{~g}$ dry soil in $50 \mathrm{~mL}$ ) (Cottenie et al. 1982). Total concentrations of metals were analysed in soil and plant samples digested with $\mathrm{HNO}_{3}\left(65 \%\right.$ ultra-pure) and $\mathrm{H}_{2} \mathrm{O}_{2}$ (70\% ultra-pure) in a Speedwave Xpert Berghof microwave oven. Deionised water was used for diluting the digests. Fe, $\mathrm{Mn}$, and Zn levels were detected by FAAS (Flame Atomic Absorption Spectrometry, Avanta PM GBC) and those of As, Cd, Co, Cr, Cu, Ni, Pb and Ti by GFAAS (Perkin-Elmer PinAAcle 900Z Graphite Furnace Atomic Absorption Spectrometry). The elements were detected against atomic absorption standard solution (Sigma Chemical Co.) and blanks of the same matrix as the samples. Element concentrations were calculated on a dry weight basis. Mercury was determined in powdered soil and plant samples by an AMA 254 Advanced Mercury Analyser. Accuracy of all elements was controlled with chestnut soil, Bainaimao and Bayan Obo, Neil Mongol in China GBW07402 (GSS-2) and Poaceae (mixture) IPE 952WEPAL Certified Reference
Materials and presented in ESM 1 and ESM 2. All analyses were performed in triplicate.

\section{Statistical analysis}

Normality and homogeneity of variance of the data were controlled with Shapiro-Wilk's W and Brown-Forsythe tests (Argaç 2004). Because normal distribution was not detected for most of the examined elements, non-parametric tests were applied. Differences in altitude, temperature, $\mathrm{pH}$ and metal contents in soils and in C. vulgaris, E. nigrum, T. praecox and $F$. vivipara between geothermal and control sites were compared with a Mann-Whitney $U$ test $(\mathrm{P}<0.05)$. Multiple comparisons of mean ranks for soils and plants were applied to evaluate differences between the species within geothermal and control sites $(\mathrm{P}<0.05)$.

Pearson correlation was applied for data with normal distribution.

To compare Ti accumulation from soil by C. vulgaris, E. nigrum, $F$. vivipara and $T$. praecox, an ANCOVA model 
was applied. In this model, the independent variable (covariate) was the Ti content available in soil, the dependent variable was Ti content in plants and the categorical predictor variable was each species. The interaction between the species and Ti concentration in soil tested the hypothesis whether the slopes of regression lines were equal between the species. If the slopes were not significantly different, we further tested whether the intercepts were equal. When significant differences were found, multiple comparison among intercepts was determined by the Tukey test (Zar 1999). A significance level of $\mathrm{P}<0.05$ was used throughout the study.

The bioaccumulation factor (BF) was calculated by dividing the element concentration in above-ground parts of C. vulgaris, E. nigrum, $T$. praecox and $F$. vivipara by the available element concentration in soil (Kandziora-Ciupa et al. 2017).

Statistica from Dell Inc (2016) was used for all calculations.

\section{Results and discussion}

\section{Soil}

Geothermal soils did not differ from control soils in altitude, but their temperature was significantly higher with more alkaline $\mathrm{pH}$ (U Mann Whitney test) than control sites (ESM 3). The maximum total metal contents for Icelandic soil presented by Panek and Kepinska (2002) were ( $\left.\mathrm{mg} \mathrm{kg}^{-1}\right) \mathrm{Cd} 0.2-1.6, \mathrm{Cu}$ 52-144, $\mathrm{Pb} 2.8-11$ and $\mathrm{Zn} 65-124$. In comparison with these data, the $\mathrm{Cd}$ content in the examined soil was lower and those of $\mathrm{Cu}, \mathrm{Pb}$ and $\mathrm{Zn}$ were higher. The maximum concentrations of $\mathrm{Co}, \mathrm{Cr}, \mathrm{Cu}, \mathrm{Fe}, \mathrm{Hg}, \mathrm{Mn}$ and $\mathrm{Zn}$ in geothermal sites were higher than those reported by Kolon et al. (2020) for Icelandic soil (ESM 3). The maximum total As concentration found was higher than the allowable level of $20 \mathrm{mg} \mathrm{kg}^{-1}$ in agricultural soil (Kabata-Pendias 2001). The Hg content of the control sites was within the average range of $0.05-0.3 \mathrm{mg} \mathrm{kg}^{-1}$ given by Kabata-Pendias (2001) and within the range of 0.01 to $0.3 \mathrm{mg} \mathrm{kg}^{-1}$ reported by Pastrana-Corral et al. (2016) for Mexican geothermal sites. The Hg content in the investigated geothermal sites was higher (ESM 3) than the abovementioned values. The maximum total concentration of $\mathrm{Ti}$ in the examined soil of geothermal sites was lower than the level of $26,000 \mathrm{mg} \mathrm{kg}^{-1}$ reported in a similar area of New Zealand (Given 1980) but higher than $3300 \mathrm{mg} \mathrm{kg}^{-1}$ given by KabataPendias (2001) as a global average for soils. Soils from geothermal sites contained significantly more (U Mann-Whitney test) total $\mathrm{As}, \mathrm{Cr}, \mathrm{Fe}, \mathrm{Hg}$, Ti and $\mathrm{Zn}$ than control soils (ESM $3)$. This is in agreement with Wilberscheid (2008) and Boothroyda (2009) that areas with geothermal activity are usually enriched with metals, especially As and Ti. Plantavailable (DTPA) soil concentrations in Icelandic geothermal zones (ESM 4) were higher than reported by Burns and Leathwick (1995) for a similar area in New Zealand (in mg $\mathrm{kg}^{-1}$ ): $\mathrm{Cu}$ 0.05-0.7, Fe 31-153, Mn 2.5-7.5 and Zn 0.2-1.5. These authors report that levels of $\mathrm{Cu}$ and $\mathrm{Zn}$ in such areas are rather low, those of $\mathrm{Mn}$ are moderate and those of $\mathrm{Fe}$ are high with a tendency to increase with declining soil temperature. In this investigation, there was no significant difference in the concentration of available $\mathrm{Fe}$ in soil between geothermal and control zones (Burns and Leathwick 1995). Plant-available soil metal concentrations were lower (except for Mn) than those presented in ESM 4 for soil samples from other nongeothermal areas in Iceland (Kolon et al. 2020). Soils from the control sites in Iceland contained significantly more (U MannWhitney test) plant-available $\mathrm{As}, \mathrm{Cu}, \mathrm{Ni}$ and $\mathrm{Ti}$ and significantly less Mn than those from geothermal sites (ESM 4). This phenomenon was probably caused by low quantities of organic material in the geothermal soils (Wilberscheid 2008). Increased organic matter levels in the soil are related to lower availability of, for example, Mn (Graham et al. 1988).

\section{Plants}

The maximum mass fractions of $\mathrm{Cr}, \mathrm{Cu}, \mathrm{Fe}$ and $\mathrm{Ni}$ in C. vulgaris (Table 1) from Iceland were higher and those of $\mathrm{Cd}, \mathrm{Mn}, \mathrm{Pb}$ and $\mathrm{Zn}$ were lower than in the same species from Karkonosze (SW Poland) reported by Wojtuń et al. (2017) and lower except for $\mathrm{Fe}$ than those from unpolluted sites in the Tatra National Park investigated by Šoltés et al. (2014) and Gjengedal et al. (2015). Maximum levels of Fe and Mn were higher and those of $\mathrm{Cu}$ and $\mathrm{Zn}$ were lower than in this species found $0.5 \mathrm{~km}$ from a Cu-Ni smelter $\left(\mathrm{mg} \mathrm{kg}^{-1}\right)$ : $\mathrm{Cu} 285, \mathrm{Fe}$ 3896, Zn 205 and Mn 60 (Monni et al. 2002). Remarkable were the concentrations of $\mathrm{Mn}$ and $\mathrm{Ti}$ in $C$. vulgaris from this investigation as they approached the values typical for toxicity thresholds in plants: $400-1000$ and $50-200 \mathrm{mg} \mathrm{kg}^{-1}$, respectively (Kabata-Pendias 2001). In spite of the fact that $\mathrm{Mn}$ is an essential trace element in plant oxidation and reduction processes, it may be harmful when accumulated in excess (Mousavi et al. 2011; Millaleo et al. 2020). Multiple comparisons of mean ranks showed that $C$. vulgaris contained significantly higher concentrations of Mn than all the other examined species. This is in agreement with Wojtuń et al. (2017) who reported $C$. vulgaris from the Karkonosze with elevated Mn concentrations higher than $400 \mathrm{mg} \mathrm{kg}^{-1}$ in shoots with the highest $\mathrm{BF}$ for this element compared to the BFs for other elements. Although $\mathrm{Mn}$ is most available for plants at low soil $\mathrm{pH}$, in the investigated soil, this factor was close to 7 both in geothermal and control sites. Nonetheless, $C$. vulgaris accumulated very high amounts of $\mathrm{Mn}$. The possible explanation is that $C$. vulgaris possesses long-lived leaves, and therefore, it can accumulate Mn over much longer periods of time compared to other studied species (Losfeld et al. 2015; Kula et al. 2018). Ericaceae typically have ericoid mycorrhizas which 
Table 1 Minimum, maximum, median and median absolute deviation (MAD) of the concentration ( $\mathrm{mg} \cdot \mathrm{kg}^{-1}$ ) of metals in Calluna vulgaris. $\mathrm{P}$ for the U Mann-Whitney test comparing geothermal and control sites.
Karkonosze: data from the Karkonosze National Park podzol (Wojtuń et al. 2017). Tatra: data from the Tatra National Park, acid and sandy soils (Šoltés et al. 2014) and organic-rich, podzolic soil (Gjengedal et al. 2015)

\begin{tabular}{|c|c|c|c|c|c|c|c|c|c|c|c|}
\hline & \multicolumn{4}{|l|}{ Geothermal } & \multicolumn{4}{|l|}{ Control } & \multirow[b]{2}{*}{$\mathrm{p}$} & \multirow[b]{2}{*}{ Karkonosze } & \multirow[b]{2}{*}{ Tatra } \\
\hline & Minimum & Maximum & Median & MAD & Minimum & Maximum & Median & MAD & & & \\
\hline As & BDL & 3 & & & BDL & BDL & & & & & \\
\hline $\mathrm{Cd}$ & 0.01 & 0.06 & 0.04 & 0.01 & 0.001 & 0.02 & 0.007 & 0.01 & $<0.01$ & $0.001-0.2$ & $0.1-0.8$ \\
\hline Co & 0.4 & 5 & 1.2 & 0.8 & 0.2 & 0.4 & 0.3 & 0.1 & $<0.01$ & & \\
\hline $\mathrm{Cr}$ & 1.0 & 12 & 3.5 & 2.5 & 1.9 & 3 & 2.3 & 0.3 & NS & $0.04-0.3$ & $0.2-6.4$ \\
\hline $\mathrm{Cu}$ & 5.8 & 17 & 11 & 4.1 & 5.2 & 7.6 & 6.6 & 0.7 & $<0.05$ & $5.6-13$ & $4-14$ \\
\hline $\mathrm{Fe}$ & 534 & 5870 & 2075 & 1375 & 498 & 930 & 779 & 16 & $<0.05$ & $49-150$ & $170-710$ \\
\hline $\mathrm{Hg}$ & 0.01 & 0.03 & 0.02 & 0.003 & 0.005 & 0.02 & 0.01 & 0.009 & NS & & \\
\hline $\mathrm{Mn}$ & 289 & 659 & 557 & 24.7 & 310 & 548 & 520 & 20.8 & NS & $68-844$ & $248-880$ \\
\hline $\mathrm{Ni}$ & 3.6 & 9.5 & 3.9 & 0.2 & 1.4 & 4.7 & 3.2 & 0.7 & $<0.05$ & $0.4-5.0$ & \\
\hline $\mathrm{Pb}$ & 0.03 & 0.3 & 0.2 & 0.01 & 0.1 & 0.3 & 0.2 & 0.01 & NS & $0.4-3.2$ & $4-9.2$ \\
\hline $\mathrm{Ti}$ & 129 & 1180 & 388 & 234 & 68 & 361 & 233 & 2.1 & NS & & \\
\hline $\mathrm{Zn}$ & 3.5 & 9 & 6.9 & 1.1 & 5.7 & 6.8 & 6.4 & 0.3 & NS & $13-38$ & $28-95$ \\
\hline
\end{tabular}

$\mathrm{NS}=$ not significant; $\mathrm{BDL}=$ detection limit for $\mathrm{As}<0.1 \mathrm{mg} \mathrm{kg}^{-1}$

can capture Mn (Hashem 1995). This has been reflected in the presented results and applies both to $C$. vulgaris and E. nigrum as both belong to the Ericaceae family. Additionally it is known that some species can secrete carboxylates from roots to soil to facilitate P uptake (DeGroote et al. 2018; Lambers et al. 2020). The side effect of this process can be also the increased availability of soil $\mathrm{Mn}$, which enters root cells by nonspecific transporters. It was proved that some Ericaceous species can also release carboxylates (Millaleo et al. 2020). The excessive soil Mn content can alter ability to absorb and accumulate other elements such as $\mathrm{Ca}, \mathrm{Fe}, \mathrm{Mg}$ (Millaleo et al. 2010). The reflection of that statement can be observed in our results as well in the case of $\mathrm{Fe}$ accumulation in C. vulgaris. Mn is recognised by Millaleo et al. (2010) as an element that concentrates mainly in plant shoots. These findings are in contradiction with the reports that found C. vulgaris as a pioneer metallophyte species having an exclusion mechanism (Monni et al. 2000; Salemaa and Uotila 2001; Lottermoser et al. 2011). Because E. nigrum also belongs to the Ericaceae family, the reasons mentioned above for C. vulgaris also apply to this species, and similar results can be observed. Unlike for C. vulgaris, $\mathrm{Mn}$ accumulation in E. nigrum was clearly observed only in geothermal sites. The maximum concentrations of $\mathrm{Cu}, \mathrm{Fe}$ and $\mathrm{Ni}$ in E. nigrum from geothermal sites were higher, and those of $\mathrm{Cd}, \mathrm{Pb}$ and $\mathrm{Zn}$ were lower in comparison with the average levels given by KabataPendias (2001) for terrestrial plants (Table 2). The Ti concentration was within the toxicity thresholds for plants also in this species (Kabata-Pendias 2001). The maximum concentrations of $\mathrm{Cd}, \mathrm{Cu} \mathrm{Fe}$ and $\mathrm{Ni}$ in F. vivipara from Iceland (Table 3) were higher, and those of $\mathrm{Pb}$ and $\mathrm{Zn}$ were lower than the average values for terrestrial plants in Table 2 (KabataPendias 2001). Ti concentration in this species was within the toxicity thresholds for plants (Kabata-Pendias 2001). The maximum concentration of $\mathrm{Cr}$ was also higher than the harmful levels for plants of 5-30 $\mathrm{mg} \mathrm{kg}^{-1}$ (Kabata-Pendias 2001). There is no evidence for the indispensability of $\mathrm{Cr}$ for plants, but some research proves that small additions of $\mathrm{Cr}$ stimulate plant growth and productivity (da Conceição Gomesa et al. 2017). Multiple comparisons of mean ranks showed that $F$. vivipara contained significantly higher concentrations of all the examined elements except for $\mathrm{Cu}, \mathrm{Mn}$ and $\mathrm{Zn}$ than the three other species. The maximum concentration of $\mathrm{Cd}$, $\mathrm{Cu}, \mathrm{Ni}$ and $\mathrm{Pb}$ in T. praecox from Iceland was higher for $\mathrm{Cu}$, $\mathrm{Fe}, \mathrm{Ni}$ and $\mathrm{Zn}$ than the average values for terrestrial plants (Tables 2 and 4) reported by Kabata-Pendias (2001). Multiple comparisons of mean ranks showed that $T$. praecox contained significantly higher $\mathrm{Zn}$ concentration than C. vulgaris, E. nigrum and $F$. vivipara. The ability to accumulate very high $\mathrm{Zn}$ amounts (up to $50 \mathrm{mg} \mathrm{kg}^{-1}$ ) was found for other species from the Thymus genus, e.g. T. serpyllum (Figas et al. 2021). Ti concentration was within the toxicity thresholds for plants also in this species (Kabata-Pendias 2001). Titanium, not considered an essential nutrient in the production of plants and recognised as a potentially harmful metal, may have positive effects (facilitate the uptake of both macroand micronutrients, increase enzymatic activity and carbohydrate production) when applied at low doses in the so called "hormesis" effect (Markert et al. 2015; Bacilieri et al. 2017). Especially foliar fertilisation can be beneficial because the $\mathrm{Ti}$ 
Table 2 Minimum, maximum, median and median absolute deviation (MAD) of the concentration $\left(\mathrm{mg} \cdot \mathrm{kg}^{-1}\right)$ of metals in Empetrum nigrum. P for U Mann-Whitney test comparing geothermal and control sites. Plants: average data from Kabata-Pendias (2001) for terrestrial plants

\begin{tabular}{|c|c|c|c|c|c|c|c|c|c|c|}
\hline & \multicolumn{4}{|l|}{ Geothermal } & \multicolumn{4}{|l|}{ Control } & \multirow[b]{2}{*}{$\mathrm{p}$} & \multirow[b]{2}{*}{ Plants } \\
\hline & Minimum & Maximum & Median & MAD & Minimum & Maximum & Median & MAD & & \\
\hline As & BDL & 2.1 & & & $\mathrm{BDL}$ & 1.2 & & & & \\
\hline $\mathrm{Cd}$ & 0.01 & 0.1 & 0.02 & 0.01 & 0.004 & 0.02 & 0.006 & 0.005 & $<0.001$ & $<0.2$ \\
\hline Co & 0.2 & 2.7 & 1 & 0.6 & 0.1 & 2 & 0.7 & 0.2 & NS & \\
\hline $\mathrm{Cr}$ & 0.5 & 13 & 4.7 & 2.9 & 1.1 & 9.1 & 2.7 & 1 & NS & \\
\hline $\mathrm{Cu}$ & 4 & 12 & 6.7 & 1.8 & 3.6 & 8.3 & 6.6 & 0.5 & NS & $<0.5$ \\
\hline $\mathrm{Fe}$ & 376 & 3776 & 1811 & 940 & 175 & 2536 & 1150 & 323 & NS & $<350$ \\
\hline $\mathrm{Hg}$ & 0.01 & 1.2 & 0.03 & 0.03 & 0.01 & 0.02 & 0.01 & 0.003 & NS & \\
\hline $\mathrm{Mn}$ & 169 & 366 & 302 & 50 & 77 & 590 & 136 & 46 & $<0.01$ & \\
\hline $\mathrm{Ni}$ & 2.8 & 8.7 & 4.9 & 1.1 & 3.3 & 8.1 & 4.9 & 1.6 & NS & $<1$ \\
\hline $\mathrm{Pb}$ & 0.04 & 0.4 & 0.1 & 0.05 & 0.1 & 0.4 & 0.2 & 0.08 & NS & $<2.5$ \\
\hline $\mathrm{Ti}$ & 106 & 1482 & 549 & 308 & 35 & 818 & 266 & 155 & $<0.05$ & \\
\hline $\mathrm{Zn}$ & 4.4 & 6.9 & 5.3 & 0.7 & 4.4 & 19 & 10 & 4 & $<0.001$ & $<30$ \\
\hline
\end{tabular}

$\mathrm{NS}=$ not significant; $\mathrm{BDL}=$ detection limit for $\mathrm{As}<0.1 \mathrm{mg} \mathrm{kg}^{-1}$

supply via soil is not effective as the element shows low mobility in soil and limited uptake by roots. The average Ti concentration in terrestrial plants is $0.1-10 \mathrm{mg} \mathrm{kg}^{-1}$ (Markert 1992; Tlustoš et al. 2005). The content of this element in plants collected by Ceccantini et al. (1995) from a similar bedrock in Brazil was $1-32 \mathrm{mg} \mathrm{kg}^{-1}$. Remarkable was that all the species examined in this investigation contained elevated Ti levels. Tlustoš et al. (2005) believe that Ti accumulates mostly in assimilating tissues, but the usual concentration in plants is rather low. Soils of geothermal fields usually also contain high levels of Ti, among others. This metal is rather mobile in soil solution (Glime 2007; Chiarucci et al. 2008;
Wilberscheid 2008; Boothroyda 2009; Lyu et al. 2017) and therefore available for plants by transport through roots (Lyu et al. 2017). Remarkable was also the positive relation between the concentration of Ti available in soil and Ti concentration in C. vulgaris, E. nigrum, F. vivipara and T. praecox from geothermal sites. ANCOVA showed homogeneity of slopes among these species $\left(F_{3,21}=0.62, p=0.610\right.$, ESMs 5 and 6). This indicates that the relationships between Ti concentration in soil and that in plants are similar in all examined species. Significant differences in intercepts were found among the species $\left(\mathrm{F}_{3,24}=7.64, \mathrm{p}<0.001\right.$, ESMs 5 and 6$)$. Multiple comparisons of intercepts among the species showed
Table 3 Minimum, maximum, median and median absolute deviation (MAD) of the concentration $\left(\mathrm{mg} \cdot \mathrm{kg}^{-1}\right)$ of metals in Festuca vivipara. P for U MannWhitney test comparing geothermal and control sites

\begin{tabular}{|c|c|c|c|c|c|c|c|c|c|}
\hline & \multicolumn{4}{|l|}{ Geothermal } & \multicolumn{4}{|l|}{ Control } & \multirow[b]{2}{*}{$\mathrm{p}$} \\
\hline & Minimum & Maximum & Median & MAD & Minimum & Maximum & Median & MAD & \\
\hline As & BDL & 39 & & & BDL & 20 & & & NS \\
\hline $\mathrm{Cd}$ & 0.03 & 0.6 & 0.05 & 0.01 & 0.02 & 0.4 & 0.06 & 0.07 & NS \\
\hline Co & 0.6 & 13 & 4.4 & 2.7 & 0.3 & 16 & 1.6 & 1.2 & NS \\
\hline $\mathrm{Cr}$ & 2.2 & 53 & 10.3 & 7 & 1.8 & 60 & 5.8 & 3 & NS \\
\hline $\mathrm{Cu}$ & 3.7 & 57 & 10 & 6.6 & 4.6 & 40 & 6.1 & 0.6 & NS \\
\hline $\mathrm{Fe}$ & 1010 & 15496 & 5932 & 3354 & 456 & 12817 & 2163 & 1436 & NS \\
\hline $\mathrm{Hg}$ & 0.02 & 0.06 & 0.04 & 0.01 & 0.01 & 0.03 & 0.02 & 0.005 & $<0.05$ \\
\hline $\mathrm{Mn}$ & 107 & 250 & 168 & 38 & 134 & 406 & 217 & 53 & $<0.05$ \\
\hline $\mathrm{Ni}$ & 2.7 & 23 & 6.8 & 3 & 1.8 & 45 & 5.7 & 3.8 & NS \\
\hline $\mathrm{Pb}$ & 0.1 & 1.8 & 0.3 & 0.06 & 0.04 & 1.1 & 0.2 & 0.1 & $<0.05$ \\
\hline $\mathrm{Ti}$ & 236 & 1868 & 849 & 442 & 105 & 2307 & 788 & 769 & NS \\
\hline $\mathrm{Zn}$ & 8.1 & 18 & 9.4 & 1.1 & 7.7 & 47 & 15 & 8.7 & $<0.05$ \\
\hline
\end{tabular}

NS = not significant 
Table 4 Minimum, maximum, median and median absolute deviation (MAD) of the concentration $\left(\mathrm{mg}^{\mathrm{kg}} \mathrm{kg}^{-1}\right.$ ) of metals in Thymus praecox. $\mathrm{P}$ for $\mathrm{U}$ Mann-Whitney test comparing geothermal and control sites. Opole: data for T. vulgaris from experimental field in Opole (Rajfur 2015)

\begin{tabular}{|c|c|c|c|c|c|c|c|c|c|c|}
\hline & \multicolumn{4}{|l|}{ Geothermal } & \multicolumn{4}{|l|}{ Control } & \multirow[b]{2}{*}{$\mathrm{p}$} & \multirow[b]{2}{*}{ Opole } \\
\hline & Minimum & Maximum & Median & MAD & Minimum & Maximum & Median & MAD & & \\
\hline As & BDL & 4.7 & & & BDL & 1.1 & & & & \\
\hline $\mathrm{Cd}$ & 0.03 & 0.1 & 0.06 & 0.02 & 0.01 & 0.08 & 0.02 & 0.003 & $<0.001$ & $<0.7$ \\
\hline Co & 0.4 & 6.2 & 1.4 & 0.53 & 0.3 & 4.2 & 0.99 & 0.6 & NS & \\
\hline $\mathrm{Cr}$ & 0.8 & 15 & 2.9 & 1.7 & 1.3 & 6.8 & 3.3 & 0.9 & NS & \\
\hline $\mathrm{Cu}$ & 5.1 & 16 & 9.2 & 3.7 & 6.3 & 11 & 7.7 & 1.2 & NS & $<23$ \\
\hline $\mathrm{Fe}$ & 534 & 7647 & 1969 & 981 & 405 & 3576 & 1358 & 470 & $<0.05$ & $<821$ \\
\hline $\mathrm{Hg}$ & 0.02 & 0.1 & 0.03 & 0.001 & 0.01 & 0.02 & 0.01 & 0.002 & $<0.01$ & \\
\hline $\mathrm{Mn}$ & 79 & 236 & 114 & 28 & 44 & 259 & 110 & 30 & NS & $<110$ \\
\hline $\mathrm{Ni}$ & 1.5 & 9.3 & 2.6 & 0.9 & 1 & 8.5 & 4.8 & 1.1 & NS & $<34$ \\
\hline $\mathrm{Pb}$ & 0.01 & 0.6 & 0.2 & 0.05 & 0.001 & 0.3 & 0.1 & 0.1 & NS & $<3.5$ \\
\hline $\mathrm{Ti}$ & 181 & 1496 & 559 & 251 & 64 & 707 & 409 & 144 & NS & \\
\hline $\mathrm{Zn}$ & 21 & 42 & 25 & 3.1 & 14 & 54 & 28 & 9 & NS & $<25$ \\
\hline
\end{tabular}

NS = not significant

that the intercept for $F$. vivipara was significantly higher than for C. vulgaris, E. nigrum and T. praecox (ESMs 5 and 6). This means that monocotyledon $F$. vivipara would have the highest concentration of Ti in above-ground parts at any concentration of Ti available in soil in comparison to all the dicotyledonous species examined.

The U Mann-Whitney test revealed that $C$. vulgaris from geothermal sites was enriched in $\mathrm{Cd}, \mathrm{Co}, \mathrm{Cu}, \mathrm{Fe}$ and $\mathrm{Ni}$; E. nigrum was enriched in $\mathrm{Cd}, \mathrm{Mn}$ and $\mathrm{Ti} ; F$. vivipara in $\mathrm{Hg}$ and $\mathrm{Pb}$; and T. praecox in $\mathrm{Cd}, \mathrm{Fe}$ and $\mathrm{Hg}$ in comparison with the same species from the control sites. Geothermal fields are usually enriched in various trace elements (Given 1980; Lorenzini 2002; Durowoju et al. 2016). Zn concentration in $E$. nigrum and $F$. vivipara was significantly higher in plants from control sites than from geothermal sites (Tables 2 and 3). This was probably caused by low quantity of organic material in the geothermal soils (Wilberscheid 2008). An increased organic matter level in the soil is related to enhanced $\mathrm{Zn}$ availability (Moody et al. (1997).

\section{Bioaccumulation factor}

A bioaccumulation factor $(\mathrm{BF})>1$ shows that a species is able to accumulate an element from soil to above-ground tissues (Cluis 2004; Galal and Shehata 2015; Rajfur 2015). All species from both the geothermal and control sites of Iceland had $\mathrm{BF}<1$ for $\mathrm{Cd}$ and $\mathrm{Pb}$ (except for $C$. vulgaris from all sites and F. vivipara from geothermal sites) (ESMs 7 and 8). This means that the elements were not transferred from soil to above-ground parts of the species (Cluis 2004; Galal and Shehata 2015). Lead is recognised as immobile in alkaline soils thus being not available for plants. However, the acidic to neutral (ESM 3) pH of the examined soils should be favourable for $\mathrm{Pb}$ mobility. Both $\mathrm{Cd}$ and $\mathrm{Pb}$ are toxic for plants (Nagajyoti et al. 2010) and therefore accumulated mainly in roots to protect the photosynthetic apparatus (KabataPendias 2001). Marrs and Bannister (2006) report that the highest concentrations of $\mathrm{Pb}$ in $C$. vulgaris were located in the roots and the lowest were in the thin stems and green shoots. $\mathrm{BF}>1$ for $\mathrm{Pb}$ in $C$. vulgaris means that this species is able to accumulate $\mathrm{Pb}$ also in shoots (Bartoli et al. 2013). This is in contradiction to Monschein et al. (2010), Lottermoser et al. (2011) and Pippucci et al. (2015) who found C. vulgaris as a species with an exclusion mechanism which did not accumulate high levels of metals and thus was able to survive in contaminated mine waste. Various species of Festuca, e.g. Festuca arundinacea, F. vivipara, Festuca ovina and Festuca rubra, have been reported as metal-tolerant with prevailing accumulation in roots (Wong 1982; Brown and Brinkmann 1992; Sigurður and Björn 2005; Szczęśniak 2005; Albornoz et al. 2016; Shabani et al. 2016). Thus, BF $>1$ for most of the elements in $F$. vivipara from this investigation shows that the species probably also has accumulation ability in shoots (Fei et al. 2018). E. nigrum is recognised as a species with internal metal tolerance (Monni et al. 2000) and accumulates higher metal levels mainly in the old stem tissue when growing in polluted sites (Monni et al. 2002). This investigation also reports $T$. vulgaris, with $\mathrm{BF}>1$ for most of the elements, as a metal accumulator. The enhanced antioxidant capacity, mainly due to increased accumulation of phenolic compounds, most likely confers protection against the toxic influence of metals to this species (Petrović et al. 2015; Zayova et al. 2018). The highest median BF indicating intensive accumulation for the species growing in geothermal and 
control areas was found for Ti and $\mathrm{Mn}$ for $C$. vulgaris, Ti and $\mathrm{Cr}$ for E. nigrum and F. vivipara and Ti and $\mathrm{Zn}$ for T. praecox. The highest median BF indicating intensive accumulation for the species growing in geothermal and control areas was found for $\mathrm{Ti}$ and $\mathrm{Mn}$ for $\mathrm{C}$. vulgaris, $\mathrm{Ti}$ and $\mathrm{Cr}$ for $E$. nigrum and $F$. vivipara and $\mathrm{Ti}$ and $\mathrm{Zn}$ for $T$. praecox. Thus, Ti was well accumulated by species belonging to various classes (monocotyledons: F. vivipara) and (dicotyledons: C. vulgaris, E. nigrum, T. praecox) as well as various families: Ericaceae (C. vulgaris, E. nigrum) and Lamiaceae (T. praecox). The reason why this occurs needs further investigation. According to Kabata-Pendias (2001), Ti is a metal with the lowest bioaccumulation factor in plants contrary to the easily available and mobile Zn. Cook et al. (2009) also report Ti as an element abundant in soil but with low concentrations in plants. Obviously this does not apply to the high Ti concentrations as observed in plants in geothermal areas.

\section{Conclusion}

1. C. vulgaris from geothermal sites was enriched in $\mathrm{Cd}, \mathrm{Co}$, $\mathrm{Cu}, \mathrm{Fe}$ and $\mathrm{Ni}$; E. nigrum was enriched in $\mathrm{Cd}, \mathrm{Mn}$ and $\mathrm{Ti}$; $F$. vivipara in $\mathrm{Hg}$ and $\mathrm{Pb}$; and $T$. praecox in $\mathrm{Cd}, \mathrm{Fe}$ and $\mathrm{Hg}$ in comparison with the same species from the control sites.

2. C. vulgaris, E. nigrum, F. vivipara and T. praecox were distinguished by remarkably high concentrations of $\mathrm{Ti}$ and C. vulgaris also of $\mathrm{Mn}$ in amounts typical of toxicity thresholds.

3. $\quad \mathrm{Cd}$ and $\mathrm{Pb}$ (except for $C$. vulgaris and $F$. vivipara) were not accumulated in the shoots of geothermal plants.

4. F. vivipara from geothermal sites had the highest concentration of Ti in above-ground parts at any concentration of plant-available Ti in soil.

Supplementary Information The online version contains supplementary material available at https://doi.org/10.1007/s11356-021-15046-3.

Authors' contributions Adam Rajsz - searching for sites, collection of samples in the field, preparation of samples for analyses, preparation of Fig. 1. Bronisław Wojtun - initiation of the study, supervision, searching for sites and recognition of plant species, searching for references, statistical evaluation of data. Aleksandra Samecka-Cymerman - initiation of the study; supervision; writing, reviewing and editing with input from Bronisław Wojtuń; statistical evaluation of data with input from Bronisław Wojtuń; preparation of tables, ESMs 1-4 and 7-8; searching for references. Paweł Wasowicz-initiation of the study, supervision, perfect logistic organisation of field work, searching for sites and recognition of plant species, collection of samples in the field, preparation of samples for analyses. Lucyna Mróz - formal analysis, ANCOVA analysis with relating references and drawing ESM 5 and ESM 6. Andrzej
Rudecki-chemical analyses of samples. Alexander J. Kemperschecking the correctness of the English language.

Data Availability The datasets used and/or analysed during the current study are available from the corresponding author on reasonable request.

\section{Declarations}

Ethical approval This article does not contain any studies with human participants or animals performed by any of the authors.

Consent to participate Not applicable.

Consent to publish Not applicable.

Competing interests The authors declare that they have no competing interests.

Open Access This article is licensed under a Creative Commons Attribution 4.0 International License, which permits use, sharing, adaptation, distribution and reproduction in any medium or format, as long as you give appropriate credit to the original author(s) and the source, provide a link to the Creative Commons licence, and indicate if changes were made. The images or other third party material in this article are included in the article's Creative Commons licence, unless indicated otherwise in a credit line to the material. If material is not included in the article's Creative Commons licence and your intended use is not permitted by statutory regulation or exceeds the permitted use, you will need to obtain permission directly from the copyright holder. To view a copy of this licence, visit http://creativecommons.org/licenses/by/4.0/.

\section{References}

Aboal JR, Pérez-Llamazares A, Carballeira A, Giordano S, Fernández JA (2011) Should moss samples used as biomonitors of atmospheric contamination be washed? Atmos Environ 45:6837-6840

Albornoz CB, Larsen K, Landa R, Quiroga MA, Najle R, Marcovecchio J (2016) Lead and zinc determinations in Festuca arundinacea and Cynodon dactylon collected from contaminated soils in Tandil (Buenos Aires Province, Argentina). Environ Earth Sci 75:742

Argaç D (2004) Testing for homogeneity in a general one-way classification with fixed effects: power simulations and comparative study. Comput Stat Data Anal 44:603-612

Arnalds Ó, Óskarsson H (2009) Íslensk jarðvegskort. Náttúrufræðingurinn 78(3-4):141-153

Bacilieri FS, Pereira de Vasconcelos AC, Quintão Lana RM, Mageste JG, Rodrigues Torres JL (2017) Titanium (Ti) in plant nutrition - a review. Aust J Crop Sci 11:382-386

Bartoli G, Bottega S, Forino LMC, Castiglione MR, Castiglione MR, Tagliasacchi AM, Grilli I, Spanò C (2013) Morpho-physiological plasticity contributes to tolerance of Calluna vulgaris in an active geothermal field. Aust J Bot 61:107-118

Boothroyda IKG (2009) Ecological characteristics and management of geothermal systems of the Taupo Volcanic Zone, New Zealand. Geothermics 38:200-209

Brown G, Brinkmann K (1992) Heavy metal tolerance in Festuca ovina L. from contaminated sites in the Eifel Mountains, Germany. Plant Soil 143:239-247

Burns B, Leathwick J (1995) Geothermal vegetation dynamics geothermal vegetation dynamics. Sci Conserv 18:5-25 
Ceccantini G, Figueiredo AMG, Sondag F, Soubles F (1995) Rare earth elements and titanium in plants, soils and ground waters in the alkaline-ultramafic complex of Salitre, MG, Brazil. Contaminated Soils. 3rd international Proceedings of Conference on the Biogeochemistry of Trace Elements Paris (France), May 15-19

Chiarucci A, Calderisi M, Casini F, Bonini I (2008) Vegetation at the limits for vegetation: Vascular plants, bryophytes and lichens in a geothermal field. Folia Geobot 43:19-33

Cluis C (2004) Junk-greedy greens: phytoremediation as a new option for soil decontamination. Biotechnol J 2:60-67

Cook LL, McGonigle TR, Inouye RS (2009) Titanium as an indicator of residual soil on arid-land plants. J Environ Qual 38:188-199

Cottenie A, Verloo M, Kiekens L, Velghe G, Camerlynck R (1982) Chemical analysis of plant and soil. Laboratory of Analytical and Agrochemistry. State University Ghent, Belgium, pp 100-129

da Conceição Gomesa MA, Hauser-Davis RA, Suzuki MS, Vitória AP (2017) Plant chromium uptake and transport, physiological effects and recent advances in molecular investigations. Ecotoxicol Environ Saf 140:55-64

DeGroote KV, McCartha GL, Pollard AJ (2018) Interactions of the manganese hyperaccumulator Phytolacca americana L. with soil $\mathrm{pH}$ and phosphate. Ecol Res 33:749-755

Dell Inc (2016) Dell Statistica (data analysis software system), version 13. software. dell.com

Dradrach A, Karczewska A, Szopka K (2020) Arsenic accumulation by red fescue (Festuca rubra) growing in mine. affected soils - findings from the field and greenhouse studies. Chemosphere 248:126045

Durowoju OS, Odiyo JO, Ekosse G-IE (2016) Variations of heavy metals from geothermal spring to surrounding soil and Mangifera indica Siloam Village, Limpopo Province, sustainability. MDPI, Open Access J 8:1-12

Elmarsdóttir Á, Vilmundardóttir OK, Magnússon SH (2015) Vegetation of high-temperature geothermal areas in Iceland. Proceedings World Geothermal Congress 2015, Melbourne

Engelskjøn T, Lund L, Alsos IG (2003) Twenty of the most thermophilous vascular plant species in Svalbard and their conservation state. Polar Res 22:317-339

Fei L, Xu P, Dong Q, Mo Q, Wang ZL (2018) Young leaf protection from cadmium accumulation and regulation of nitrilotriacetic acid in tall fescue (Festuca arundinacea) and Kentucky bluegrass (Poa pratensis). Chemosphere 212:124-132

Figas A, Tomaszewska-Sowa M, Kobierski M, Sawilska AK, Klimkowska K (2021) Hazard of contamination with heavy metals in Thymus serpyllum L. herbs from rural areas. Agriculture 11:375. https://doi.org/10.3390/agriculture11040375

Galal TM, Shehata HS (2015) Biaccumulation and translocation of heavy metals by Plantago major L. grown in contaminated soils under the effect of traffic pollution. Ecol Indic 48:244-251

Given DR (1980) Vegetation on heated soils at Karapiti, central North Island, New Zealand, and its relation to ground. New Zeal J Bot 18: $1-13$

Gjengedal E, Martinsen T, Steinnes E (2015) Background levels of some major, trace, and rare earth elements in indigenous plant species growing in Norway and the influence of soil acidification, soil parent material, and seasonal variation on these levels. Environ Monit Assess 187:386

Glime JM (2007) Bryophyte Ecology, Vol 1 Physiol Ecol, published online

Graham RD, Osmond G, Hannam RJ, Uren NC (1988) Manganese in soils and plants. Kluwer Academic Publishers, Dordrecht

Hashem AR (1995) The role of mycorrhizal infection in the resistance of Vaccinium macrocarpon to manganese. Mycorrhiza 5:289-291

Kabata-Pendias A (2001) Trace elements in soils and plants. CRC Press, Boca Raton

Kandziora-Ciupa M, Nadgórska-Socha A, Barczyk G, Ciepał R (2017) Bioaccumulation of heavy metals and ecophysiological responses to heavy metal stress in selected populations of Vaccinium myrtillus $\mathrm{L}$. and Vaccinium vitis-idaea L. Ecotoxicology 26:966-980

Kolon M, Kopeć M, Wojtuń B, Samecka-Cymermana A, Mróz L, Wąsowicz P, Rajsz A, Kempers AJ (2020) Sanionia uncinata, Racomitrium lanuginosum and Salix herbacea as ecological indicators of metals in Iceland. Ecol Indic 112:106058

Kristinsson H (2010) Flowering Plants and Ferns of Iceland. Mál og menning, Reykjavík

Kula E, Wildová E, Hrdlička P (2018) Accumulation and dynamics of manganese content in bilberry (Vaccinium myrtillus L.). Environ Monit Assess 190:1-12

Lambers H, Wright IJ, Pereira CG, Bellingham PJ, Bentley LP, Boonman A, Cernusak LA, Foulds W, Gleason SM, Gray EP, Hayes PE, Kooyman RM, Malhi Y, Richardson SJ, Shane MW, Staudinger C, Stock WD, Swarts ND, Turner BL, Turner J, Veneklaas EJ, Wasaki J, Westoby M, Xu Y (2020) Leaf manganese concentrations as a tool to assess belowground plant functioning in phosphorusimpoverished environments. Plant Soil. https://doi.org/10.1007/ s11104-020-04690-2

Lorenzini G (2002) Trace elements in vegetables grown in an area exposed to the emissions of geothermal power plants. Fresen. Environ Bull 11:137-142

Losfeld G, L'huillier L, Fogliani B, Mc Coy S, Grison C, Jaffré T (2015) Leaf-age and soil-plant relationships: key factors for reporting traceelements hyperaccumulation by plants and design applications. Environ Sci Pollut Res 22:5620-5632

Lottermoser BG, Glass HJ, Page CN (2011) Sustainable natural remediation of abandoned tailings by metal-excluding heather (Calluna vulgaris) and gorse (Ulex europaeus), Carnon Valley, Cornwall, UK. Ecol Eng 37:1249-1253

Lyu S, Wei X, Chen J, Wang C, Wang X, Pan D (2017) Titanium as a beneficial element for crop production. Front Plant Sci 8:597

Markert B (1992) Presence and significance of naturally occurring chemical elements of the periodic system in the plant organism and consequences for future investigations on inorganic environmental chemistry in ecosystems. Vegetatio 103:1-30

Markert B, Fränzle S, Wünschmann S (2015) Chemical evolution: definition, history, discipline. In: Markert B, Fränzle S, Wünschmann S (eds) Chemical Evolution. Springer, Cham, Heidelberg, New York, Dordrecht London, pp 1-62

Marrs RH, Bannister P (2006) The adaptation of Calluna vulgaris (L.) Hull to contrasting soil types. New Phytol 81:753-761

Millaleo R, Reyes-Díaz M, Ivanov AG, Mora ML, Alberdi M (2010) Mn as essential and toxic element for plants. J Soil Sci Plant Nutr 10: 476-494

Millaleo R, Alvear M, Aguilera P, González-Villagra J, de la Luz MM, Alberdi M, Reyes-Díaz M (2020) Mn toxicity differentially affects physiological and biochemical features in highbush blueberry (Vaccinium corymbosum L.) cultivars. J Soil Sci Plant Nutr 20: 795-805

Mousavi SR, Shahsavari M, Rezaei M, Rezaei MA (2011) General Overview On Manganese (Mn) Importance For Crops Production. Aust J Basic Appl Sci 5:1799-1803

Moody PW, Yo SA, Aitken RL (1997) Soil organic carbon, permanganate fractions, and the chemical properties of acid soils. Aust J Soil Res 35:1301-1308

Monni S, Bücking H, Kottke I (2002) Ultrastructural element localization by EDXS in Empetrum nigrum 2002. Micron 33:339-351

Monni S, Salemaa M, Milar N (2000) The tolerance of Empetrum nigrum to copper and nickel. Environ Pollut 109:221-229

Monni S, Uhlig C, Hansen E, Magel E (2001) Ecophysiological responses of Empetrum nigrum to heavy metal pollution. Environ Pollut 112:121-129

Monschein M, Neira JI, Kunert O, Bucar F (2010) Phytochemistry of heather (Calluna vulgaris (L.) Hull.) and its altitudinal alteration. Phytochem Rev 9:205 
Nagajyoti PC, Lee KD, Sreekanth TVM (2010) Heavy metals, occurrence and toxicity for plants: a review. Environ Chem Lett 8:199216

Nishar A, Bader MK-F, O'Gorman EJ, Deng J, Breen B, Leuzinger S (2017) Temperature effects on biomass and regeneration of vegetation in a geothermal area. Front Plant Sci 8:249

Oliva SR, Valdés B (2004) Influence of washing on metal concentration in leaf tissue. Commun Soil Sci Plant Anal 35:1543-1552

Ottósson JG, Sveinsdóttir A, Harðardóttir M (2016) Vistgerðir á Íslandi. Fjölrit Náttúrufræðistofnunar 54:299

Panek E, Kepinska B (2002) Trace metal (Cd, Cu, Pb, Zn) and sulphur content in soils and selected plant species of Iceland. A pilot study. Icel Agric Sci 15:3-9

Pastrana-Corral MA, Wakida FT, García-Flores E, Rodriguez-Mendivil DD, Quiñonez-Plaza A, Piñon-Colin TDJ (2016) Soil mercury levels in the area surrounding the Cerro Prieto geothermal complex. Mexico Environ Monit Assess 188:1-11

Peel M, Finlayson B, McMahon T (2007) Updated world map of the Köppen-Geiger climate classification. Hydrol Earth Syst Sci Discuss 4:439-473

Petrović VN, Petrović S, Slobodan JD, Francišković M (2015) Essential oil and extracts from Thymus praecox Opiz ssp. polytrichus as natural antioxidants. Arch TechnSci 13:51-57

Pigott CD (1955) Thymus L. J Ecol 43:365

Pippucci A, Lorenzi R, Spano C, Sorce C (2015) Stress-induced changes to the flora in a geothermal field in central Italy. Acta Physiol Plant $37: 10$

Rajfur M (2015) Fitokumulacja metali ciężkich w wybranych gatunkach ziół [Heavy metals phytoaccumulation in selected species of herbs]. Proceed Ecopole 9:685-692

Redman RS, Sheehan KB, Stout RG, Rodriguez RJ, Henson JM (2002) Thermotolerance generated by plant/fungal symbiosis. Science 22 : 2985598,1581

Salemaa M, Uotila T (2001) Seed bank composition and seedling survival in forest soil polluted with heavy metals. Basic Appl Ecol 2:251263

Shabani L, Sabzalian MR, Mostafavi S (2016) Arbuscular mycorrhiza affects nickel translocation and expression of $\mathrm{ABC}$ transporter and metallothionein genes in Festuca arundinacea. Mycorrhiza 26:6776

Sigurður HM, Björn T (2005) Heavy metals and sulphur in mosses at Grundartangi in 2005 Styrkur pungmálma og brennisteins í mosa á
Grundartanga og nágrenni árið 2005. Mynd á kápu: Séð að ¡ðjuverunum á Grundartanga frá sýnatökustað G6. Ljósm. Sigurður H. Magnússon, 14.9. 2005. ISSN 1670-0120

Šoltés R, Gregušková E, Šoltésová A (2014) Bioindication of chemical elements deposition in the high Tatra Mts (Slovakia) based on Calluna vulgaris (L.) Hull; comparative levels after the improvement of emissions. Carpath. J Earth Env Sci 9:5-14

Stout RG, Al-Niemi TS (2002) Heat tolerant flowering plants of active geothermal areas in Yellowstone National Park. Ann Bot 90:259 267

Szczęśniak E (2005) Species of Festuca ovina group (Poaceae) on the serpentine rocks in the Sudety Foreland. Acta Bot Siles 2:121-129

Tlustoš P, Cígler P, Hrubý M, Kužel S, Száková J, Balík J (2005) The role of titanium in biomass production and its influence on essential elements' contents in field growing crops. Plant Soil Environ 51: $19-25$

Wasowicz P 2020. Annotated checklist of vascular plants of Iceland. Fjölrit Náttúrufraeđistofnunar.

Wojtun B, Samecka-Cymerman A, Żołnierz L, Rajsz A, Kempers AJ (2017) Vascular plants as ecological indicators of metals in alpine vegetation (Karkonosze, SW Poland). Environ Sci Pollut Res 24: 20093-20103

Wilberscheid S (2008) Bryophyte vegetation in geothermal areas in Iceland Diplomar beitzur Erlangung des Grades einer DiplomBiologinder Mathematisch-Naturwissenschaftlichen Fakultätder Rheinischen-Friedrich-Wilhelms-Universität Bonn. Arch Bryol Special 4:1-78 ISSN 0945-3466

Wong MH (1982) Metal co tolerance to cooper, lead, and zinc in Festuca rubra. Environ Res 29:42-47

Zar H (1999) Biostatistical analysis. Prentice Hall, Upper Saddle River

Zayova E, Stancheva I, Geneva M, Hristozkova M, Dimitrova L, Petrova M, Sichanova M, Salamon I, Mudroncekova S (2018) Arbuscular mycorrhizal fungi enhance antioxidant capacity of in vitro propagated garden thyme (Thymus vulgaris L.). Symbiosis 74:177-187

Zverev VE, Zvereva EL, Kozlov MV (2008) Slow growth of Empetrum nigrum in industrial barrens: Combined effect of pollution and age of extant plants. Environ Pollut 156:454-460

Publisher's note Springer Nature remains neutral with regard to jurisdictional claims in published maps and institutional affiliations. 